\title{
Determination of Anti-Inflammatory Activity of Coumarin Compounds of Coldenia Procumbens Linn
}

\author{
S. Babu ${ }^{1 *}$, V. Ambikapathy ${ }^{2}$ and A. Panneerselvam ${ }^{3}$ \\ ${ }^{1,2,3}$ Department of Botany and Microbiology, A.V.V.M. Sri Pushpam College, Poondi Thanjavur, India
}

Available online at: www.isroset.org

Received: 18/Aug/2018, Accepted: 22/Sept/2018, Online: 31/Oct/2018

\begin{abstract}
In the present study, invitro anti-inflammatory activity was tested using coumarin compound of C.procumbens. Coumarins are a group of polyphenolic compounds isolated by TLC method from C.procumbens plant extract. In antiinflammation study, the methanolic extract showed high percentage of inhibition observed in egg albumin denaturation studies was $78.8 \%$ of $0.8 \mu \mathrm{g} / \mathrm{ml}$ concentration of coumarin compounds where as compared to standard drug Diclofenac sodium $74.8 \%$. While, bovine serum albumin denaturation assay was $67.8 \%$ of $0.8 \mu \mathrm{g} / \mathrm{ml}$ concentration when compared to other concentration of coumarin compounds. The results were discussed.
\end{abstract}

Keywords: C.procumbens, coumarin, BSA, Egg albumin

\section{INTRODUCTION}

Inflammation is a normal protective response to tissue injury and it involves a complex array of enzyme activation, mediator release, fluid extravasations, cell migration, tissue breakdown and repair (Vane et al., 1995). It is a complex process, which is frequently associated with pain and involves occurrences such as the increase in vascular permeability, increase of protein denaturation and membrane alterations (Umapathy et al., 2010). In other words "Inflammation is the major and complex reaction of the body against infection upon tissue injury." But in some conditions appears to be no resolution and a chronic state of inflammation develops that may last the life of the individual. Such conditions include the inflammatory disorders rheumatoid arthritis, osteoarthritis, inflammatory bowel diseases, retinitis, multiple sclerosis, psoriasis and atherosclerosis. Inflammation has a very big variety of pathological and physiological response. In India, the Science of Ayurveda has provided a system of medical treatment. Most of the remedies for treating illnesses are being taken from plants. During the last few decades, much work has been done in the field of these natural products.

Coldenia procumbens Linn. (Boraginaceae) is a prostrate herb called as "Tripakshi" in Sanskrit, "Tripungki" in Hindi and "Seruppadai" or "Saruseruppadai" in Tamil. It is found commonly in wastelands, agriculture fields and ponds during summer season as a weed. Fresh leaves, dried plants and seeds are medicinally useful for human life (Chopra et al., 1956; Kiritikar and Basu, 1980).

\section{MATERIALS AND METHODS}

\section{Sample collection}

The whole plants of Coldenia procumbens were collected from harvesting paddy field of N.V Kudikadu, Thanjavur district, Tamilnadu, India. The plant C.procumbens was authenticated by Rapinat Harbarium St. Josesph's College, Trichy.

\section{Preparation of plant extract}

The whole plant materials were washed and shade dried. These dried materials are pulverized to attain a coarse powder. Twenty five gm of the plant material was extracted with different solvents (acetone, ethanol, methanol and aqueous) $100 \mathrm{ml}$ using a Soxhlet apparatus for $5 \mathrm{hrs}$. The extracts was filtered through Whatman No.1 filter paper and stored in refrigerator. The extract was used for further investigation.

\section{Separation of Coumarins compounds by thin layer chromatography}

Thin layer chromatographic plates were prepared by making a slurry containing silica gel in distilled water; the ratio of adsorbent with water is $1: 2(\mathrm{v} / \mathrm{v})$. The slurry was applied with glass plates by using a spreader or manually with the help of glass rod to get homogenous layer. These plates were dried at room temperature and activated by heating at $100^{\circ} \mathrm{C}$ for 30 minutes in an oven. The dried plates were spotted with conc. ethanolic solution of extracts by the help of the capillary action. Spots were dried in front of air blower. Spotted TLC plates were developed with 
Chloroform: acetone $(83: 17 \mathrm{v} / \mathrm{v})$ to get best resolution and dried at room temperature. 5\% methanolic solution of potassium hydroxide was sprayed on thin layer chromatograms. When inspected in long wave UV light (365 $\mathrm{nm})$ as well as in visible lights, spots appeared as yellow fluorescent (Nyiredy, 2001).

The RF values of the various bioactive compounds were calculated using the following formula:

$$
\mathrm{Rf}_{=} \begin{gathered}
\text { Distance travelled by solute } \\
-\mathrm{Distance} \text { travelled by solvent }
\end{gathered}
$$

\section{In vitro egg albumin denaturation method (Rahman et al., 2015)}

A mixture of $0.2 \mathrm{ml}$ of egg albumin, $2.8 \mathrm{ml}$ of Phosphate buffer ( $\mathrm{pH}$ 6.4) and different concentrations (0.2, $0.4,0.6,0.8$ and $1.0 \mu \mathrm{l} / \mathrm{ml}$ ) of Coumarin compounds of Coldenia procumbens was used as the test and used as the standard drug. A similar volume of double distilled water served the control. The above mixtures were incubated at $37 \pm 2^{\circ} \mathrm{C}$, for $15 \mathrm{~min}$ and then heated at $70^{\circ} \mathrm{C}$ for $5 \mathrm{~min}$. The test was repeated 3 times. After cooling the absorbance was measured at $660 \mathrm{~nm}$ using multi-mode micro plate reader (Synergy Biotech, USA). The percentage inhibition of denaturation, which is an index of anti-inflammatory activity was calculated using the following formula:

$\%$ of Inhibition $=100 \times(\mathrm{At} / \mathrm{Ac}-1)$

Where, $A t=$ absorbance of the test sample, Ac $=$ absorbance of the control

\section{In vitro BSA denaturation method (Williams et al., 2008)}

A solution of $0.2 \% \mathrm{w} / \mathrm{v}$ of BSA was prepared in Tris buffer saline and $\mathrm{pH}$ was adjusted to 6.8 using glacial acetic acid. Different concentrations $(0.2,0.4,0.6,0.8$ and $1.0 \mu \mathrm{l} / \mathrm{ml}$ ) of Coumarin compounds of Coldenia procumbens and Diclofenac sodium was used as the test sample and standard. The test tubes were heated at $72^{\circ} \mathrm{C}$ for 5 minutes and then cooled for 10 minutes. The absorbance of these solutions was determined by using UV spectrophotometer at $660 \mathrm{~nm}$. The percentage of inhibition of precipitation (denaturation of the protein) was determined on the percentage basis relative to the control using the following formula.

$$
\% \text { of Inhibition }=100 \mathrm{X}(\mathrm{At} / \mathrm{Ac}-1)
$$

Where, $\mathrm{At}=$ absorbance of the test sample, Ac = absorbance of the control.

\section{RESULTS AND DISCUSSION}

In Ayurveda and traditional medicines, there are several records of treating people suffering from pain and inflammation with plants. Inflammatory responses occur in three distinct phases, an acute, transient phase characterized by local vasodilation and increased capillary permeability. There are several records on plants in Ayurveda and traditional medicines/ethno medicines which focused on relief from pain, swelling, fever, inflammation and rheumatism. The present investigation suggested that the provided scientific support to rationalize the folklore or traditional claim of the selected plants for treating inflammation (Mizushima and Kobayashi, 1968).

In the present investigation, coumarin compounds were isolated from C.procumbens aerial plants by TLC. The Chloroform: acetone mobile phase showed good separation of analyzed compounds in $\mathrm{Rf}$ value $2.5 \mathrm{~cm}$ identifed. Muratovic et al. (2013) reported the coumarine derivates prettified by TLC method. Amri et al. (2018) evaluated that the $P$. atlantica leaves showed the presence of flavonoids, terpenes, tannins, coumarin tannins, and the absence of alkaloids and saponins. In addition of gallic acid derivatives, 3 glycosylated flavonoids were identified. The compounds corresponded to rutin, quercetrin and heterosides of quercetin, kaempferol and myricetin identified by TLC method.

The analysis of the phytochemical constituents of plants aids the screening of their biological activities (Cox and Balick, 1994) and has great interest in pharmaceutical companies for the production of new drugs. The phytochemicals are the plants secondary metabolites that help the plant to combat competitors, predators or pathogens (Kennedy Wightman, 2011).

It was previously reported that leukocytes proteinase play an important role in the development of tissue damage during inflammatory reactions and significant level of protection was provided by proteinase inhibitors (Das and Chatterjee, 1995, Leelaprakash and Mohan Dass, 2011). In the current study, anti-inflammation study of egg albumin (EA) and Bovine serum albumin (BSA) were selected for the invitro assessment of coumarin compounds. The coumarin compounds with standard drug measured the percentage of inhibition was 43.5, 57.2, 63.5, 67.5 and 65.5 $\%$ of $0.2,0.4,0.6,0.8$ and $1.0 \mu \mathrm{l} / \mathrm{ml}$ concentration of coumarin derivative compounds and the standard drug measured the percentage of inhibition was 40.5, 56.8, 61.4, 66.2 and 63.4 percentage of cell damage at $0.2,0.4,0.6,0.8$ and $1.0 \mu \mathrm{l}$ concentration of Diclofenac sodium respectively. Because, the plant extract which containing extraordinary group of coumarin compounds were represented (Table 1).

Some researchers reported that the denaturation of proteins is one of the causes of inflammation. In certain rheumatic diseases, the production of auto-antigens may be due to denaturation of proteins (Zhao et al., 2008). Antiinflammatory drugs are known to inhibit the denaturation of proteins (Chatterjee et al., 2012 and Mizushima, 1966). Non-steroidal anti-inflammatory drugs are the major pharmacological agents used for the anti-inflammatory and pain-relief management due to their capacity in inhibiting protein denaturation (Saso et al., 2001 and Heendeniya et al., 2018). Therefore, agents that can prevent the denaturation could be used for the development of antiinflammatory drugs. Mizushima and Kobayashi (1968) 
studied invitro screening models to assess the protein denaturation. In the present investigation revealed the egg albumin denaturation was $0.8 \mu \mathrm{g} / \mathrm{ml}$ of coumarin extracts recorded high percentage of inhibition when compared to other concentrations (Table 2).

Table 1: Determination of BSA denaturation activity of Coumarin compounds

\begin{tabular}{|c|c|c|}
\hline \multicolumn{2}{|l|}{$\begin{array}{l}\text { Concentration } \\
\text { of } \\
(\boldsymbol{\mu g} / \mathbf{m l})\end{array}$} & \multicolumn{2}{|c|}{$\begin{array}{c}\text { Percentage of } \\
\text { inhibition (\%) }\end{array}$} \\
\cline { 2 - 3 } & Coumarin & $\begin{array}{c}\text { Diclofenac } \\
\text { Sodium }\end{array}$ \\
\hline 0.2 & 43.5 & 40.5 \\
\hline 0.4 & 57.2 & 56.8 \\
\hline 0.6 & 63.5 & 61.4 \\
\hline 0.8 & 67.8 & 66.2 \\
\hline 1.0 & 65.5 & 63.4 \\
\hline
\end{tabular}

Table 2: Determination of egg albumin denaturation activity of Coumarin compounds

\begin{tabular}{|c|c|c|}
\hline $\begin{array}{c}\text { Concentration of } \\
\text { extract }(\boldsymbol{\mu g} / \mathbf{m l})\end{array}$ & \multicolumn{2}{|c|}{$\begin{array}{c}\text { Percentage of } \\
\text { inhibition }(\%)\end{array}$} \\
\cline { 2 - 3 } & Coumarin & $\begin{array}{c}\text { Diclofenac } \\
\text { Sodium }\end{array}$ \\
\hline 0.2 & 54.1 & 53.2 \\
\hline 0.4 & 63.1 & 62.4 \\
\hline 0.6 & 76.3 & 74.3 \\
\hline 0.8 & 78.8 & 74.8 \\
\hline 1.0 & 76.5 & 71.3 \\
\hline
\end{tabular}

\section{ACKNOWLEDGEMENT}

The authors extend sincere thanks to the principal, A.V.V.M Sri Pushpam College, Poondi and the Director, Indian Biotrack Research Institute, Thanjavur for the laboratory facilities provided.

\section{REFERENCE}

[1]. Amri, O., Zekhnini, A., Bouhaimi, A., Tahrouch, S. and Hatimi, A., (2018). Anti-inflammatory activity of methanolic extract from Pistacia atlantica Desf. leaves. Pharmacog J.; 10(1):71-6.

[2]. Chatterjee P, Chanda S, Dev P., and Bhattacharya S. (2012). Evaluation of anti-inflammatory effects of green tea and black tea: a comparative in vitro study. Journal of Advanced Pharmaceutical Technology and Research.; 3(2):136-138.

[3]. Chopra, R.N., Nayar, S.L. and Chopra, I.C., (1956). Glossary of Indian Medicinal Plants. CSIR, New Delhi.

[4]. Cox, P.A. and Balick, M.J., (1994). The ethnobotanical approach to drug discovery. Scientific American.; 270(6):60-65.
[5]. Das, S.N. and Chatterjee, S., (1995). Long term toxicity study of ART-400. Indian Indg Med; 16 (2): 117-123

[6]. Dinarello C., (2010). Anti-inflammatory Agents: Present and Future. Cell; 140: 935-950.

[7]. Heendeniya, SN., Ratnasooriya WD. and Pathirana, RN., (2018). In vitro investigation of anti-inflammatory activity and evaluation of phytochemical profile of Syzygium caryophyllatum. J. of Pharmaco. and Phytochem.; 7(1): 1759-1763.

[8]. Kennedy and Wightman. (2011). Herbal extracts and phytochemicals: plant secondary metabolites and the enhancement of human brain Function1. Advance in. Nutrition.; 2:32-50.

[9]. Kiritikar, K.R. and Basu, B.D., (1980). Indian Medicinal Plants, V. 1-4. Bishen Singh Mahendra Pal Singh, Dehra Dun.

[10]. Leelaprakash G. and Mohan Dass S., (2011). "Invitro Antiinflammatory activity of Methanol extract of Enicostemma Axillare. Int. J. Drug Dev. and Res., 3(3): 189-196.

[11]. Medzhitov R., (2010). Inflammation: New Adventures of an Old Flame. Cell; 140: 771-776.

[12]. Mizushima Y. and Kobayashi M., (1968). Interaction of antiinflammatory drugs with serum proteins, especially with some biologically active proteins. Pharmacy and Pharmacology.; 20:169-73.

[13]. Mizushima Y., (1966). Screening test for anti-rheumatic drugs. Lancet.; 2:443-448.

[14]. Muratovic, S. Osmanovic, A., Veljovic, E., Dzudzevic-Cancar, H., Duric, K., Niksic, H. and Zavrsnik, (2013). Evaluation of purity of some coumarin derivatives by melting point measurements, TLC and scanning densitometry. Bulletin of the Chemists and Technologists of Bosnia and Herzegovina.: 41: 1519

[15]. Nyiredy, S. (2001). Planar Chromatography a Retrospective View for the Third Millenium. 36-42. Springer Scientific Publisher, Budapest.

[16]. Rahman, H., Eswaraiah, M.C. and Dutta, A.M., (2015). In-vitro antiinflammatory and anti-arthritic activity of Oriza sativa Var. Joha Rice (An Aromatic Indigenous Rice of Assam). American Eurasian Journal of Agricultural and Environmental Sciences.; 15(1):115-121.

[17]. Saso, L, Valentini, G, Casini, ML, Grippa, E, Gatto, MT. and Silvestrini, B. (2001). Inhibition of heat-induced denaturation of nonsteroidal antiinflammatry drugs (NSAIDs): pharmacological implications. Archives of Pharma. Research.; 24(2):150-158.

[18]. Umapathy, E., Ndebia, E.J., Meeme, A., Adam, B., Menziura, P., Nkeh-Chungag, B.N. and Iputo, J.E., (2010). An experimental evaluation of Albuca setosa aqueous extract on membrane stabilization, protein denaturation and white blood cell migration during acute inflammation. J.of Medicinal Plant Res.; 4 (5) 789 795.

[19]. Vane, J.R. and Botting, R.M., (1995). New insights into the mode of action of anti-inflammatory drugs. Inflammation Res.; 44 (1) 110.

[20]. Williams L.A., O'Connar, A., Latore, L., Dennis, O., Ringer, S., Whittaker, J.A., Conrad, J., Vogler, B., Rosner, H. and Kraus, W., (2008). The in vitro anti-denaturation effects induced by natural products and non-steroidal compounds in heat treated (immunogenic) bovine serum albumin is proposed as a screening assay for the detection of anti-inflammatory compounds, without the use of animals, in the early stages of the drug discovery process. West Indian Med J. ;57(4):327-31.

[21]. Zhao HL, Harding SV, Marinangeli CP, Kim YS. and Jones PJ., (2008). Hypocholesterolemic and anti-obesity effects of saponins from Platycodon grandiflorum in hamsters fed atherogenic diets. Journal of Food Science.; 73(8):195-200. 